\title{
Assessing company strength in South Africa using value added: 1990-2000
}

\author{
C. King* \& W.D. Hamman \\ Graduate School of Business, University of Stellenbosch, \\ PO Box 610, Bellville 7535, Republic of South Africa \\ acking@mweb.co.za
}

Received March 2004

\begin{abstract}
This article aims to determine if value added-based ratio analysis could be used to measure organisation strength and be useful as a tool in corporate strategy formulation. The areas of investigation included productivity of production factors, reinvestment in capital and overall business control.

Productivity measurement provides insight into the capital and labour intensity of organisations. Some organisations were able to exert high value added to sales ratios, but they did not perform as well when their productivity levels were measured. Reinvestment in capital tries to establish if organisations have the means to uphold and strengthen their present asset base, which also includes its human capital. Margins on sales and value added are used to measure overall business control and provide insight into the ability of organisations to add value through their own production skills or by command of lucrative contracts with suppliers. Organisations that are able to show high values on both ratios are said to display a high degree of overall business control.
\end{abstract}

The formulas used in this article are a replication of those used by the mentioned authors. The models as developed by Bryant are specifically used to see how they fit in the South African context and to draw conclusions about their use for future purposes.

*To whom all correspondence should be addressed.

\section{Introduction}

Value added is not a new theory, but it was The corporate report (Accounting Standards Steering Committee), published in 1975, that formalised the concept for accounting purposes. Other financial statements are drawn up with the sole purpose to report the financial results and position of the organisation to its shareholders. The value added statement has a wider audience in mind and the idea behind it is to report to all the stakeholders of an organisation, not only shareholders, what their share of the distribution of the wealth created by the organisation is.

Much debate exists about the validity of the value added statement. Those who are for its existence claim that it is a way of social reporting and an indication of an organisation's contribution towards the gross national product. If organisations are able to increase their individual value added proportion, they would assist in the whole country's wealth creation process.

Proponents against the value added statement claim that it has no real value and does not fit within the realm of organisational operations. It does not contribute towards increased shareholder value and its mere structure could lead to negativity within an organisation. The disclosure of items such as employee costs in relation to shareholder profit could be a cause of antagonism between the stakeholders of an organisation.

The objective of this article is to establish if the value added statement could be used to assess organisation strength. An attempt is made to try and find out if ratio analysis, based on the items of the value added statement, could be used to compare organisations and identify factors that could possibly improve organisation results.

It should be noted here that the term 'sales' is used in this article instead of revenue. The composition of revenue or sales, as it was presented in the published value added statements, was inconsistent as it did not always represent the same. In some cases it represented only that which the organisation had sold during a particular year, whereas in other cases it also included the amount for interest received. The value used in this study consisted only of the actual sales by the organisation.

The literature review looks at the uses of the value added statement of which ratio analysis is one. The development of ratio analysis and current practice is also discussed. The methodology takes a look at the criteria for the sample that was used and at the various formulas that were used to derive the three models for interpretation. The results obtained from the various calculations performed are 
discussed in the same order through the article to remain consistent and for easy reference. In the summary and conclusion an attempt is made to consider the validity of ratio analysis, based on the items of a value added statement and to conclude if there is a place for it in the corporate world to assist with strategic decision making.

\section{Literature review}

\section{A tool of comparison}

Value added ratios put value added in relation to other items and are regarded as useful indicators and analytical instruments (Haller \& Stolowy, 2003: 9).

Value added-based ratios such as employee cost as a percentage of value added can be used as a useful analytical and predictive tool. In many British organisations, employees receive around 70 percent of value added. Trends in this ratio and others, in comparison with other organisations and within various sectors, may be useful. Another popular ratio is value added as a percentage of sales. This ratio measures the degree of vertical integration of a group of organisations and at the same time can be a measure of vulnerability to disruptive action that could affect supplies and materials and services. Ratios that are found to be equally useful in comparing organisations with those abroad are value added per employee and value added as a percentage of salaries and wages (Morley, 1979: 621622).

However, Rutherford (1981: 31) argues that a system of financial reporting which concentrates on value added may provide an indirect stimulus to increase this measure at the expense of shareholders. He explains that the constituents that make up value added can be increased to show an increased value added, but in the process of doing so, it might be to the detriment of the shareholders who would want to maximise their share in the organisation. Production, planning and investment analysis methods based on value added must be applied cautiously in order to avoid the counterproductive consequences of maximising value added.

Sophisticated use of value added analysis employs ratios within industries to establish a standard against which organisations of those industries can measure their own performances. This will remove the injustices of measuring all organisations over an economy-wide scheme, but it will not be able to remove the acceptable differences of say capital intensity within an industry (Rutherford, 1981: 33).

\section{A good measure of the size and importance of the organisation}

To use sales figures as a basis for organisation rankings can cause a warped impression as sales may be inflated by a large portion of bought-in cost that is passed straight on to customers. Capital employed is also sometimes misleading as a capital intensive organisation with few employees may sometimes be seen as more important than a labour intensive business. Value added does not have these disadvantages and is therefore superior to sales and to capital employed as a ranking basis (Morley, 1979: 622).

\section{Value added statement ratio analysis}

The value added statement provides a useful measure to help in judging performance and activity. Value added, which is represented as the net output of an organisation, can be used in relation to other key figures such as non-current assets and employee costs as significant measures of performance (The corporate report, 1975: 49-50).

Organisations vary from each other and they operate in different market environments that require diverse characteristics. Some are highly capital intensive and require huge capital layouts in order to reinvest in their future productivity. Others, such as those in the service industry, do not need to buy as many materials and services from outside. The decision to make or buy remains complex and with ever-changing conditions in world markets and technology, management needs to be highly compliant in its approach to corporate strategy and business structure (Bryant, 1989: 34).

Unfortunately, no single measure of accurately measuring the efficiency by which the merits of the organisation can be judged and the productivity of its management, employees and capital exists. Some ratios such as return on capital employed, earnings per share, dividend policy and gearing structure may provide useful insight to providers of capital and the government, but they do not provide any useful information about the efforts of the employees involved, the relative dependence and control between the organisation and its suppliers or about the long-term future of the organisation in terms of its people and the non-current assets it requires to meet its task of supplying goods and services to the market. Efforts such as the maximisation of sales or the pursuit of an aggressive acquisition policy to expand the size of the organisation may lead to some conclusions about the management of the organisation, but they do not customarily mean that these are in the best interest of a market and its developing technology. In some cases they may well be, but the expansion of profitable, self-generated capital investment in new non-current assets, training, research and development to keep up with the levels attained by the major international organisations in developed countries such as Japan, West Germany and France and with emerging low cost centres around the world, must be a goal too. It is here that value added analysis can be shown as a helpful tool for examining corporate strategy (Bryant, 1989: 34).

\section{Value added as a measure of sales}

Sales describe the extent of an organisation's business, while added value measures the overall contribution and influence of the organisation. A higher or lower than average value added to sales ratio does not necessarily mean that an organisation is more or less efficient. It may merely demonstrates that the organisation is creating a larger than average profit margin or that it sought a vertical integration strategy by being less dependent on its suppliers and owning its market outlets. Sometimes it might be the nature of the 
market to dictate a particular optimal division of the management of added value between the organisation and its suppliers or it may simply imply that the organisation has a different management and technology structure compared to others of its type (Bryant, 1989: 35).

Bryant (1989: 35) says that in practice the size of the enterprise has little to do with the ratio, value added as a percentage of sales. Figures will also vary across industries. Organisations that are horizontally diversified across different markets will experience an averaging out of this ratio as the structures of these markets are added together. Figures might indicate a tendency to decline over a period of time. An explanation for this may well be that improved technologies have changed the way goods and services are produced. Also, with outsourcing being favoured at the expense of own production capabilities, presumably to save on employee costs, organisations create less value within their organisations and thus contribute towards a declining value added to sales ratio as more goods and services are bought in than previously (Bryant, 1989: 35-38).

In an article by Steyn and Hamman (2002: 19) various scenarios were tested against a base case to evaluate the impact of increasing any of the elements on the additive side of the value added calculation and what the impact would be on the total value added. The result was that if the sales volume remains unchanged or the cost of sales and other bought-in items did not decrease in some way, value added would not increase. To increase the employee costs, for example, without a concurrent increase in sales volume would only have the effect of reducing distributions to other stakeholders as disclosed in a value added statement, without increasing total value added. The goal of the organisation should be to increase sales or decrease cost of sales in order to increase total value added. It should thus remain focussed on the goal to be more productive and efficient in its operating activities. For this reason is it important to view value added as a percentage of sales to see how much of that which was sold during the year was converted into value added.

During a study that compared the results of value added statements published in South Africa over a period of seven years, 1991 to 1997, it was found that for the ratio value added as a percentage of sales large differences emerged between the various sectors, as well as organisations within those sectors. The two predominant reasons for these results were vertical integration and profit margins. The greater the proportion of vertical integration and/or profitability, the higher the ratio value added to sales was. A rise in profit margins will lead to an increase in this ratio. The explanation for this being so is that profit after taxation is equal to dividends and retained profit and both these items are composite elements of value added (Hamman \& Burger, 1999).

\section{Productivity}

Value adding labour productivity is measured as a ratio of value added per employee. Sectors can vary greatly in this ratio and organisations within a sector can also have wide spread values. The position of a organisation depends on its strategic choices, operational excellence and investment profile (The value added scoreboard 2003, 2003: 4).

The mix of sectors that exist influences the overall labour productivity of a country. High productivity sectors are typically pharmaceuticals, oil and gas and finance. Sectors with low productivity are consumer services, while media and manufacturing are usually those sectors in between. However, it should be noted that high labour productivity could be found in organisations that are unprofitable or unsustainable (The value added scoreboard 2003, 2003: 5). The spread of value added per employee and value added as a percentage of input costs is high within sectors and it is related to the size and balance of investment in people, investment in capital equipment and in the level of research and development and skills used (The value added scoreboard 2003, 2003: 7).

Productivity is a key factor in the generation of growth, prosperity and share of world trade. It is however important to note that productivity can increase at the expense of reduced employment. The key is to increase productivity without decreasing the labour force (Bryant, 1989: 38). It is important to note that a comparison of employee numbers over years can nonetheless complicate matters as many organisations have undertaken divestures and acquisitions across a variety of markets.

Haller and Stolowy (2003: 10) say that value added per employee and value added as a percentage of non-current assets can be used to measure the efficiency with which internal production factors are used. In order to calculate the mutual influence of both production factors, labour and capital, the application of a total productivity ratio has become more popular and is defined as:

((Value added / Non-current Assets) x (Value added / Number of employees)) ${ }^{1 / 2}$.

This ratio is used to evaluate the joint productivity of capital employed and the workforce (Haller \& Stolowy, 2003: 10).

Bryant (1989: 38-39) cautioned not to hastily increase capital investment in order to increase value added per employee as this might have the effect of also reducing capital productivity. New assets usually have a much higher value than those already on the balance sheet and the increase in capital expenditure would not automatically increase the value added by the organisation. It would all depend on whether or not there is a market for such improved productive output to increase the value added portion.

It would be naïve to compare the ratios of say oil organisations with that of the industrial organisations as they differ in structure to such a great extent, but the same basic tools of assessing appropriate strategies should be applied. However, it can prove to be an effective tool to compare organisations within the same industry or sector to see how they differ and what the ratio is for organisations that do better than others in the same industry. The general goal would be to strive for overall good performance on both people and assets (Bryant, 1989: 39). 
'Labour productivity is about doing the right things, not just doing things in the right way' (The value added scoreboard 2003, 2003: 7).

\section{Capital investment and efficiency}

Value adding efficiency is determined as the ratio of value added to the major inputs of employee costs and depreciation (The value added scoreboard 2003, 2003: 4). Depreciation is included as it represents the equipment expended during the year (The value added scoreboard 2003, 2003: 24). It was found in the survey during 2003 conducted in the United Kingdom that in a group of the ten largest investment-based sectors, those organisations that had an above average value for value adding efficiency also had an above average research and development intensity or non-current assets that could back up each employee or both. The same was found for labour productivity, which also tends to rise with investment per employee. Organisations particularly use value-adding efficiency as a performance measure, since it is a pure ratio and has a relationship to profits (The value added scoreboard 2003, 2003: 5-6).

High levels of value added per employee and capital productivity are not enough to measure the effectiveness of the organisation. In general, the higher the levels of noncurrent assets in the organisation, the higher the effort will be that has to be added in order to fund the replacement of such assets as opposed to funding wage costs. It is thus the operating income of the organisation that will provide the means to reinvest in such new non-current assets. Bryant (1989: 39) uses the operating income, defined as the sum of depreciation and net profit before taxation, and divides it by value added of the organisation. This figure is plotted against the capital intensity ratio, non-current assets divided by the number of employees, to demonstrate the ability of organisations to provide for reinvestment in the future.

Capital investment will arise due to various factors. It could be due to a need to replace existing assets. It might be due to an increase in output that has actually occurred, growth in output as forecast to occur, or through management expression is planned to occur to meet a market opportunity. It is a way to improve productivity. It is for this reason that the importance of accurate output forecasting should be emphasized and management carry that responsibility to get it right (Bryant, 1989: 39-40).

Bryant (1989: 40) has found that on average organisations spent 23 percent of value added on new non-current assets. Two thirds of organisations sampled in the United Kingdom during 1987 to 1988 had an investment level below the average, which implies that the other third were spending a lot to make up for the level. Half of the organisations spent less than 15 percent of their value added on new non-current assets. This gives reason for concern over future sustained growth and productivity, especially seen in the light that the average level of operating income to value added was 44 percent. This high level should provide the means to increase capital expenditure by a very large amount.
Organisations wish to achieve a high value adding efficiency and then sustain or improve it so that their employees and equipment produce enough value added to enable sector-leading investments in the future. However, a high value adding efficiency can be achieved, in the short term, by reducing investment. It is thus necessary to adjust investment values of value adding efficiency for a sector in order to assume equivalent investment for all organisations. This would identify organisations that simultaneously achieve high value adding efficiency and high levels of investment (The value added scoreboard 2003, 2003: 5).

Riahi-Belkaoui (1992: 113-114) states that a value addedbased index as a measure of managerial efficiency can be computed by dividing value added by the organisation by the costs of the inputs of labour and capital of the organisation. Measuring the outputs relation to the inputs of that organisation, i.e. excluding the inputs of other organisations, is said to be a better measure of efficiency of the organisation in question. Value added as a ratio of the organisation's assets signifies a measure of the organisation's ability to efficiently generate value to distribute to its stakeholders. Those organisations that have a lower than industry average ratio are said to be less efficient than other organisations and could become the target of a take-over. Should value added thus be viewed as a measure of managerial competence before allocations to stakeholders and reinvestment, it is implied that target organisations were under-achievers, which may have been acquired for better use of their asset potential (Bannister \& Riahi-Belkaoui, 1991: 242).

Another measure of capital intensity is represented by depreciation as a percentage of employee costs where 100 percent represents an equal distribution of employee costs and depreciation. Depreciation is an underestimate of the use of non-current assets and is usually less than capital expenditure for most organisations, even in difficult years (The value added scoreboard 2003, 2003: 22). An organisation will invest part of its value added to sustain, develop and grow its business. This investment includes research and development and capital expenditure for new products, processes and services. It will also encompass expenditure to develop new brands and new markets, skills and systems, including new business processes (The value added scoreboard 2003, 2003: 25). In a survey done during 2002 in the United Kingdom to develop the second Value Added Scoreboard (2003: 25), it was found that less than 20 percent of the top 600 European organisations have capital expenditure below depreciation.

According to The value added scoreboard 2003 (2003: 23), a high capital intensity means that depreciation equals 65 percent of employee costs and is found in oil and gas sectors and utilities with average skill intensity levels. Lower capital intensity means that depreciation is below 30 percent of employee costs and is found amongst the higher skill intensity sectors such as finance, software, aerospace and insurance. It is also found in lower skills intensity sectors such as retail and support services, but normally these sectors are likely to employ part time workers. On the whole, those sectors with high average skills intensity tend to be those with high research and development intensity 
and higher average employee cost. Capital intensity measured as depreciation divided by employee costs is thus less.

\section{Profit strategy and vertical integration}

Vertical integration illustrates how much an entity has created value on its own through its operating activities, i.e. how independent it is of suppliers to provide products and services for its business entity to produce the products and services that it sells.

In the pursuit of a specific corporate strategy to supply goods and services to the market, a business could achieve success if it could control the maximum amount of surplus money to its benefit. Should the business be able to control margins and markets, as measured by profit before taxation divided by sales, as well as control the margin on value added as measured by profit before taxation divided by value added, it is said to have good overall business control (Bryant, 1989: 40-41).

Organisations that are able to influence suppliers in order for them to deliver products and services of high standards and quality to the market and thereby control the margins and markets are said to have high market influence. They do not necessarily control their suppliers, but are able to influence them to provide products and services that measure up to their preferred standards. On the other hand, if a organisation is able to supply through its own resources a product or service of unique quality it controls the margin on added value and can dictate product prices to customers. Organisations that are able to succeed in this measure have a high supply influence in the market. It is the business that can control the buying and selling edge over the long term that is able to charge the premium (Bryant, 1989: 41).

The ratio, value added divided by sales, can be used as a helpful instrument in measuring the vertical integration of the organisation. A fully vertically integrated organisation will have a ratio of one. If the bought-in cost of materials and services were low, the value added portion of that organisation would typically be higher than that of an organisation that is more dependent on its suppliers for bought-in goods. The ratio value added to sales for such a vertically integrated organisation would thus be higher than that of an organisation that is not as vertically integrated. This ratio can thus give an indication of the vulnerability of the organisation in terms of its suppliers (Riahi-Belkaoui, 1992: 115).

Bryant suggests that market influence be measured as profit before taxation as a percentage of sales. Supply influence is represented by profit before taxation as a percentage of value added by the organisation (Bryant, 1989: 41). These two factors are represented on a chart that shows graphically how dependent a organisation is on its suppliers and to what extent it has influence in the market as a buyer or a seller. Organisations that have a high level on both ratios are said to display a high degree of overall business control.

Bryant (1989: 41-42) suggests a way of combining both factors into one index and calls it the $\mathrm{K}$ index. It gives equal weighting to both profit ratios as a mark-up on costs before profit before taxation. The $\mathrm{K}$ index is defined as:

$\mathrm{K}=\left(\frac{\text { Sales }}{\text { Sales - Profit before taxation }}\right) \times\left(\frac{\text { Value added }}{\text { Value added - Profit before taxation }}\right)$

This graph shows at a glance how much overall business control organisations have and it could prove to be a useful tool to assess organisations in same sectors.

A successful organisation could gain several advantages by increasing its value added. Additional value added provides the means to invest in the future, reward and attract skilled employees and compensate shareholders. The extra resources created provide the organisation with options for further development and growth. Value added is likely to grow if the organisation makes good strategic choices, augment operational superiority and innovation and make wise and well thought through investments in the future. These characteristics may lead an organisation to exercise a conversion from the norm. This might include a planned expansion into related higher value added areas coupled with withdrawals from areas that are becoming commodities or where the organisation does not have the competitive advantage anymore. Good organisations will address problem areas and implement change long before mediocrity is reached (The value added scoreboard 2003, 2003: 40-41).

\section{Summary}

Developing countries need to build a stable blend of sectors that can achieve and sustain high levels of efficiency and productivity without reducing employment. It is the challenge of management in such countries to aspire to those goals in order to not only gain maximum advantage for their businesses, but for the country as a whole. Using value added bases ratios in relation to other items could prove to be the useful instruments and indicators needed to achieve this task.

The formulas used in the methodology are a replication of those used by the mentioned authors. The models as developed by Bryant are specifically used to see how they fit in the South African context and to draw conclusions about their use for future purposes.

\section{Methodology}

\section{Introduction}

This article will examine eleven ratios that are directly related to the value added statement and explore the possibility of using those ratios as instruments to assess organisation strength. Data for these ratios was obtained from published value added statements as well as from the related balance sheets and income statements. Before 2000 it was not required of organisations to publish their employee costs as part of their annual reports. Since then, it has become compulsory and it is now possible to draw up a value added statement for organisations who do not publish it as part of their annual financial statements. 
The data used for these ratios had to satisfy the following criteria:

1. The period under review is from 1990 to 2000 and only organisations that were listed on the JSE Securities Exchange South Africa during this period were considered.

2. These organisations had to publish a value added statement for each year during the whole period under review, i.e. eleven years.

3. Organisations that did publish a value added statement for eleven years from 1990 to 2000 also had to publish their yearly employee numbers during this period.

Of all the published statements of organisations examined, only 33 satisfied all three criteria that were set for this sample.

\section{Calculation of ratios}

Eleven ratios were calculated for each organisation over the eleven-year period. The ratios were sub-divided within three areas, namely productivity, capital investment and efficiency and profit and vertical integration.

\section{Productivity}

For each organisation four ratios for productivity measurement were calculated.

Value added per employee that is defined as

Value added $\div$ number of employees

Value added per non-current assets, defined as:

Value added $\mathrm{x} 100 \div$ non-current assets

Non-current assets per employee

Non-current assets $\div$ number of employees

A joint productivity index (Haller \& Stolowy, 2003: 10)

$$
\sqrt{\left(\frac{\text { Value added }}{\text { Non }- \text { current assets }}\right) \times\left(\frac{\text { Value added }}{\text { Number of employees }}\right)} \ldots
$$

\section{Capital investment and efficiency}

The three ratios calculated here were:

Operating income as a percentage of value added, calculated as

(Profit before taxation + depreciation) $\times 100 \div$ value added

Value added as a percentage of the sum of employee cost and depreciation

Value added x $100 \div$ (salaries + depreciation $)$

Depreciation as a percentage of employee costs

Depreciation x $100 \div$ salaries

\section{Profit and vertical integration}

The ratios to be used were calculated as follows:

Profit before taxation as a percentage of the sales amount

Profit before taxation $\times 100 \div$ sales

Profit before taxation as a percentage of value added

Profit before taxation $\times 100 \div$ value added

Value added as a percentage of the sales amount

Value added x $100 \div$ sales

K factor index (Bryant, 1989, 41)

$$
\mathrm{K}=\frac{1}{1-\left(\frac{\text { Profit before taxation }}{\text { Sales }}\right)} \times \frac{1}{1-\left(\frac{\text { Profit before taxation }}{\text { Value added }}\right)}
$$

\section{Testing for normality}

In a study by Jordaan, Smit \& Hamman (1994:65) it was found that financial ratios are not usually normally distributed. If a distribution is normally distributed, it can be characterized by two parameters, namely the mean and standard deviation. It was decided to test these findings on the data set in order to decide which parameters would be suitable to use for interpretation.

The Lilliefors test for normality was employed at a five percent significance level. The rejection region was $\mathrm{D}>\frac{0,886}{\sqrt{363}}=0,0465$. The results indicated that the calculated test statistic was greater than the critical value in all instances and that there were no normal distributions for each of the ratios. These results affirm the findings of the study by Jordaan, Smit and Hamman (1994:71) that by disaggregating data over sectors will provide a better chance of achieving a normal distribution.

Due to the fact that normality was not achieved in all tests conducted, it has been decided to use the median as the parameter for analysis to follow.

\section{Models for interpretation}

In the article by Bryant (1989) three models for interpretation were used. The first model (Bryant, 1989:39) is used to infer how organisations make use of their production factors in order to increase their added value. The second model (Bryant, 1989: 40) depicts organisations' capital intensity and their ability to fund replacement of those non-current assets through their profit margin. The last model is a graphic illustration of organisations' overall business control through the combination of profit margin on value added, profit margin on sales and the degree of vertical integration (Bryant, 1989: 41). These models were used as reference for interpretation of the data that were collected for this article. 


\section{Results}

\section{Value added as a measure of sales}

Table 1 provides a listing of organisations ranked according to their value added median. The table also shows the organisations ranked according to their sales median over the eleven-year period from 1990 to 2000.

Barlow Rand has the highest value added amount as well as the highest sales amount as a median over the total period, but the organisation did not score high on the ranking for the ratio as it occupied the $22^{\text {nd }}$ position. SASOL did relatively well in all the rankings, scoring second in the value added median, third in the sales median and sixth in the ranking of the ratio. This organisation was able to convert approximately 48 percent of its sales into added value.

On the opposite side is Crookes Brothers. The median value added and sales figures are virtually at the bottom end of the two rankings, with value added being the third smallest amount and sales the smallest amount of all. However, on the ratio side, this organisation produced the highest ratio of all the organisations included in the sample. This organisation was able to convert 69,8 percent of its sales over a period of eleven years into added value. Putco occupied the second position in the ranking of the ratio, but showed once again that a high ratio does not necessarily imply high values for sales and value added. It resides in the $20^{\text {th }}$ position in the value added ranking and in the $27^{\text {th }}$ position in the sales ranking.

It is demonstrated here that the figures of value added and sales should not be seen in isolation of each other. A high figure for value added and/or sales does not necessarily imply a high value added to sales ratio. The ratio equalises the playing field and makes it easier to compare organisations with each other, regardless of their size.

It would not be reasonable to judge organisations purely based on this ratio. Many factors should be taken into consideration which would include the degree to which a organisation is horizontally diversified and the level of outsourcing. However, it does provide a good indication of the organisation's contribution towards the gross domestic product. The employment of such a ratio as a benchmark to be attained by organisations within their specific sectors could serve as a guide to better overall performance in the economy and stimulate growth that is much needed in this country.

\section{Productivity measurement}

One must be cautious not to confuse the two terms, capital intensity and capital productivity. A high value for this ratio, value added as a percentage of non-current assets, could represent a low degree of capital intensity and/or a high degree of capital productivity. An organisation might be able to produce at a high level through the use of its non- current assets, without being capital intensive and vice versa.

Non-current assets per employee are the amalgamation of the ratios value added per employee and value added as a percentage of non-current assets. This ratio is thus a good indication of the proportion of non-current assets and the number of employees within organisations and sectors.

Table 2 shows the productivity ratios per organisation. Profurn is a good example of a labour intensive organisation. The ratio value added per employee shows very low values, implying that the value added amount is spread over a broad base of employees. The ratio value added as a percentage of non-current assets is very high, suggesting that good use is made of the non-current assets of the organisation. The ratio non-current assets per employee is very low, thus indicating low capital intensity.

At the opposite end of the scale are SASOL and Bicc Cafca. These organisations have high proportions of non-current assets as they form part of their production facilities. In contrast to their high values for non-current assets, these sectors have fewer employees. Their ratio for value added to the number of employees in the organisation takes on higher proportions. These sectors can thus be classified as typical capital intensive organisations. It is interesting to see that although these organisations employ relatively fewer employees to that of labour intensive industries, their employee costs are not necessarily lower. This is due to the fact that these organisations require highly skilled employees and as such pay more to keep them employed in their organisations.

Figure 1 is a graphical representation of the information on Table 2 as per the median of the ratios, value added per employee and value added as a percentage of non-current assets. A legend for the organisation names is available in Appendix A. The lines on the graph, ranging from 10 to 350 indicate zones of non-current assets per employee. The higher this value takes on, the higher the degree of capital intensity is.

Organisations that fall within the region between the 200 and 350 lines show a large degree of capital intensity. Examples of such organisations are Grindrod Unicorn Group, Sun International (Boputhatswana) and Pretoria Portland Cement Organisation. SASOL displays an even higher value with non-current assets per employee exceeding R350 000 per employee. These organisations are known for their capital intensiveness. At the opposite side of the graph are Lenco Holdings and Metro Cash and Carry with values of less than R20 000 for non-current assets per employee. Profurn and Midas also feature prominently with values of less than R10 000 for the ratio non-current assets per employee. These organisations are certainly classified as least capital intensive of all the organisations in the sample. It is however interesting to see that although Profurn and Midas are not capital intensive, both display a high degree of capital productivity as per the ratio, value added as a percentage of non-current assets. 
Table 1: Organisations ranked by value added (R'000) - Median

\begin{tabular}{|c|c|c|c|c|c|c|}
\hline & Rank & Median & Rank & Median & Rank & Median \\
\hline Organisations & & $\begin{array}{l}\text { Value } \\
\text { added }\end{array}$ & & Sales & & $\begin{array}{r}\text { Value } \\
\text { added } \\
\div \text { Sales }\end{array}$ \\
\hline Barlow Rand & 1 & 5960000 & 1 & 20835000 & 22 & $25,87 \%$ \\
\hline SASOL & 2 & 5656500 & 3 & 11954800 & 6 & $47,76 \%$ \\
\hline Tiger Brands & 3 & 2426000 & 2 & 11978700 & 26 & $21,75 \%$ \\
\hline Nampak & 4 & 2088000 & 9 & 5896700 & 11 & $35,35 \%$ \\
\hline AECI & 5 & 1923000 & 8 & 6009000 & 15 & $31,26 \%$ \\
\hline Pepkor & 6 & 1438100 & 4 & 9684636 & 30 & $14,85 \%$ \\
\hline Allied Electronics & 7 & 1214386 & 11 & 3895917 & 16 & $31,17 \%$ \\
\hline Tongaat-Hulett & 8 & 1190834 & 10 & 3972288 & 17 & $30,44 \%$ \\
\hline Reunert & 9 & 1147717 & 12 & 3512162 & 19 & $29,73 \%$ \\
\hline Pick 'n Pay Stores & 10 & 981000 & 5 & 7919500 & 31 & $12,90 \%$ \\
\hline Toyota (South Africa) & 11 & 930371 & 7 & 6037751 & 27 & $18,37 \%$ \\
\hline African Oxygen & 12 & 906923 & 15 & 1723243 & 4 & $51,05 \%$ \\
\hline $\begin{array}{l}\text { Sun International } \\
\text { (Boputhatswana) }\end{array}$ & 13 & 776482 & 16 & 1498992 & 3 & $53,29 \%$ \\
\hline Pretoria Portland Cement Co & 14 & 562671 & 19 & 1327576 & 7 & $44,23 \%$ \\
\hline Trencor & 15 & 518408 & 20 & 1104453 & 5 & $48,83 \%$ \\
\hline Power Technologies & 16 & 510418 & 13 & 1813881 & 18 & $30,21 \%$ \\
\hline Metro Cash \& Carry & 17 & 500131 & 6 & 6681258 & 33 & $7,79 \%$ \\
\hline Allied Technologies & 18 & 443277 & 18 & 1338133 & 14 & $31,88 \%$ \\
\hline Grintek & 19 & 344682 & 17 & 1375689 & 23 & $24,24 \%$ \\
\hline Putco & 20 & 335761 & 27 & 551563 & 2 & $58,49 \%$ \\
\hline Dunlop Africa & 21 & 330883 & 23 & 803563 & 8 & $41,67 \%$ \\
\hline Grinrod Unicorn Group & 22 & 304798 & 22 & 831681 & 12 & $34,62 \%$ \\
\hline Siltek & 23 & 241579 & 14 & 1747608 & 28 & $17,11 \%$ \\
\hline Chemical Services & 24 & 226188 & 21 & 899582 & 21 & $25,98 \%$ \\
\hline Lenco Holdings & 25 & 181173 & 25 & 594062 & 9 & $37,01 \%$ \\
\hline Oceana Fishing Group & 26 & 166319 & 26 & 593427 & 24 & $23,99 \%$ \\
\hline Profurn & 27 & 133958 & 29 & 371394 & 10 & $36,27 \%$ \\
\hline Cashbuild & 28 & 72619 & 24 & 609714 & 32 & $11,91 \%$ \\
\hline Midas & 29 & 63764 & 28 & 405990 & 29 & $15,85 \%$ \\
\hline Bicc Cafca & 30 & 41883 & 30 & 197128 & 25 & $22,69 \%$ \\
\hline Crookes Brothers & 31 & 36341 & 33 & 62260 & 1 & $69,80 \%$ \\
\hline Glodina Holdings & 32 & 34704 & 32 & 100302 & 13 & $33,12 \%$ \\
\hline Autopage Holdings & 33 & 32598 & 31 & 122700 & 20 & $26,57 \%$ \\
\hline
\end{tabular}


Table 2: Productivity ratios

\begin{tabular}{|c|c|c|c|}
\hline & $\begin{array}{c}\text { Value added per } \\
\text { employee } \\
\text { (R'000) } \\
\end{array}$ & $\begin{array}{c}\text { Value added per non- } \\
\text { current assets } \\
(\%) \\
\end{array}$ & $\begin{array}{c}\text { Non-current assets per } \\
\text { employee } \\
\text { (R'000) } \\
\end{array}$ \\
\hline & Median & Median & $\begin{array}{c}\text { VA per empl (Median) } \\
\div \\
\text { VA per non-current assets } \\
\text { (Median) }\end{array}$ \\
\hline AECI & 123,29 & $92,82 \%$ & 132,83 \\
\hline African Oxygen & 104,67 & $75,52 \%$ & 138,60 \\
\hline Allied Electronics & 92,07 & $319,27 \%$ & 28,84 \\
\hline Allied Technologies & 118,84 & $356,90 \%$ & 33,30 \\
\hline Autopage Holdings & 92,38 & $178,64 \%$ & 51,71 \\
\hline Barlow Rand & 112,84 & $122,11 \%$ & 92,41 \\
\hline Bicc Cafca & 163,38 & $97,31 \%$ & 167,89 \\
\hline Cashbuild & 57,67 & $190,92 \%$ & 30,21 \\
\hline Chemical Services & 151,30 & $235,82 \%$ & 64,16 \\
\hline Crookes Brothers & 16,31 & $36,06 \%$ & 45,23 \\
\hline Dunlop Africa & 67,01 & $137,05 \%$ & 48,90 \\
\hline Glodina Holdings & 55,98 & $89,54 \%$ & 62,52 \\
\hline Grinrod Unicorn Group & 113,48 & $49,83 \%$ & 227,71 \\
\hline Grintek & 170,03 & $809,27 \%$ & 21,01 \\
\hline Lenco Holdings & 27,02 & $238,66 \%$ & 11,32 \\
\hline Metro Cash \& Carry & 49,22 & $280,39 \%$ & 17,55 \\
\hline Midas & 64,70 & $709,01 \%$ & 9,12 \\
\hline Nampak & 115,69 & $132,06 \%$ & 87,60 \\
\hline Oceana Fishing Group & 144,37 & $187,42 \%$ & 77,03 \\
\hline Pepkor & 36,54 & $165,78 \%$ & 22,04 \\
\hline Pick 'n Pay Stores & 43,44 & $203,22 \%$ & 21,38 \\
\hline Power Technologies & 66,83 & $215,22 \%$ & 31,05 \\
\hline Pretoria Portland Cement Co & 159,32 & $60,46 \%$ & 263,52 \\
\hline Profurn & 53,71 & $768,42 \%$ & 6,99 \\
\hline Putco & 62,62 & $172,54 \%$ & 36,29 \\
\hline Reunert & 86,00 & $286,56 \%$ & 30,01 \\
\hline SASOL & 207,20 & $51,68 \%$ & 400,89 \\
\hline Siltek & 162,15 & $707,76 \%$ & 22,91 \\
\hline Sun International (Boputhatswana) & 85,06 & $38,20 \%$ & 222,64 \\
\hline Tiger Brands & 82,40 & $151,22 \%$ & 54,49 \\
\hline Tongaat-Hulett & 55,96 & $65,94 \%$ & 84,86 \\
\hline Toyota (South Africa) & 121,04 & $100,10 \%$ & 120,91 \\
\hline Trencor & 108,64 & $251,14 \%$ & 43,26 \\
\hline
\end{tabular}

Grintek and Siltek display a high degree of capital and labour productivity. They are not necessarily classified as capital intensive, as they have ratios in the region of R21 000 for non-current assets per employee. However, these two organisations exert a high degree of productivity on both ratios for value added per employee and value added to non-current assets.

The joint productivity index (Haller \& Stolowy, 2003:10) is an indicator of the degree to which organisations are able to use both production factors in their operations productively. Table 3 shows this ratio per organisation and is sorted in descending order according to their median.

The organisations that portrayed the highest degree in both areas of labour and capital productivity are once again shown as Siltek and Grintek. It is surprising to find Crookes Brothers right at the bottom end of the scale as this organisation has shown the highest degree of value added to sales of all organisations included in the sample. Sun International (Boputhatswana), previously mentioned for its high degree of capital intensiveness, is residing in the $31^{\text {st }}$ position. This too comes as a surprise as this organisation has also featured quite high up in the ratio of value added to sales. It would thus appear that these two organisations could do even better if they were able to mobilise their workforce and non-current assets to such an extent as to improve their value added produced.

\section{Efficiency}

Table 4 shows the values for various ratios calculated in order to show their relative efficiency. Value added as a percentage of the sum of salaries and depreciation literally implies the degree to which value was added by these two factors. 


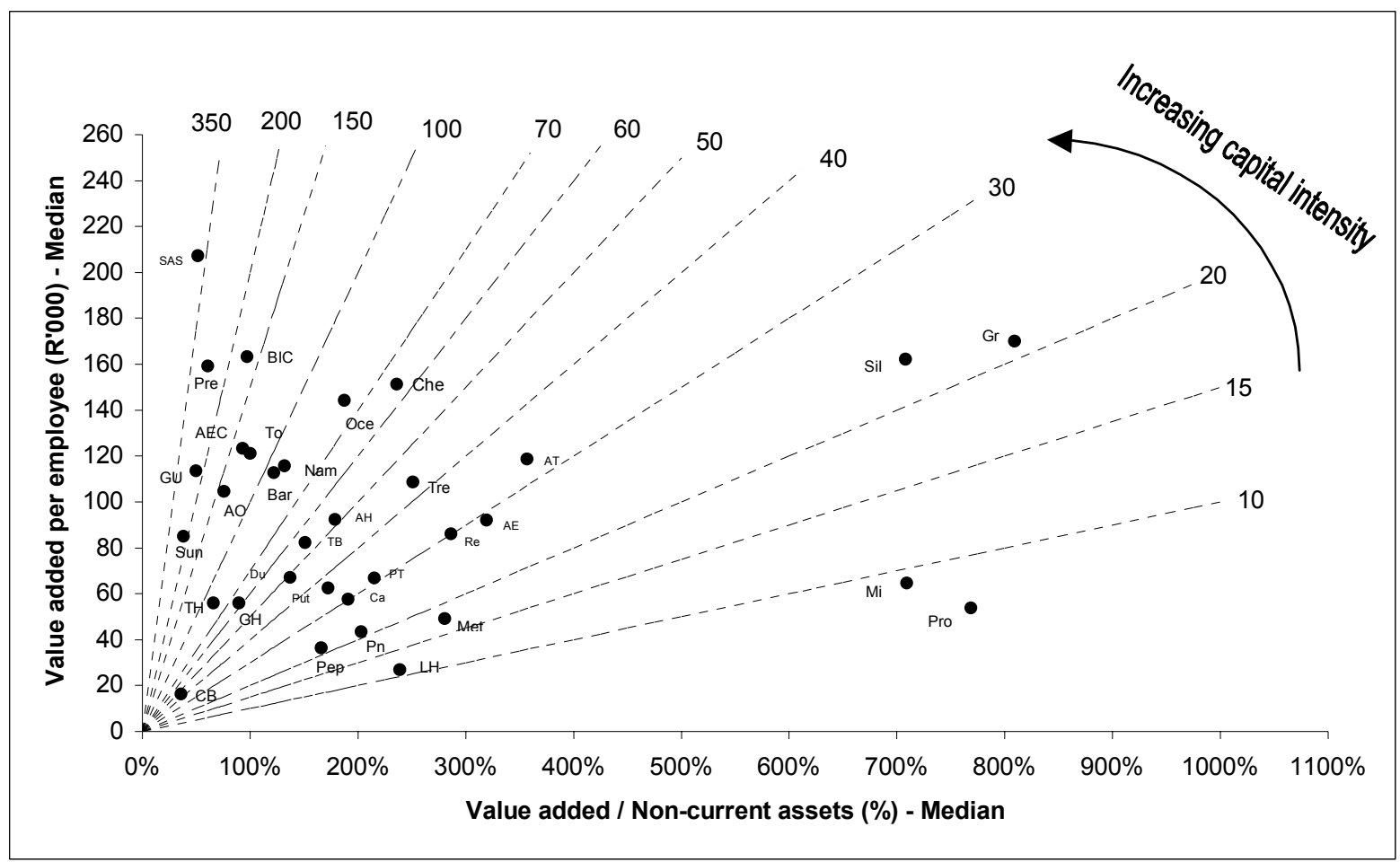

Figure 1: Capital and labour intensity per organisation: median

Table 3: Joint productivity index per organisation

\begin{tabular}{|c|c|}
\hline & Joint productivity index \\
\hline Organisations & Median \\
\hline Siltek & 46,48 \\
\hline Grintek & 42,96 \\
\hline Profurn & 29,50 \\
\hline Midas & 26,95 \\
\hline Chemical Services & 24,17 \\
\hline Allied Technologies & 23,47 \\
\hline Oceana Fishing Group & 20,58 \\
\hline Allied Electronics & 20,19 \\
\hline Reunert & 19,57 \\
\hline Trencor & 16,38 \\
\hline Barlow Rand & 16,15 \\
\hline Bicc Cafca & 15,35 \\
\hline Nampak & 15,17 \\
\hline Autopage Holdings & 15,04 \\
\hline Power Technologies & 14,50 \\
\hline Metro Cash \& Carry & 14,42 \\
\hline Toyota (South Africa) & 13,62 \\
\hline Tiger Brands & 13,54 \\
\hline Pretoria Portland Cement Co & 12,71 \\
\hline SASOL & 12,51 \\
\hline Cashbuild & 11,56 \\
\hline AECI & 11,51 \\
\hline African Oxygen & 11,35 \\
\hline Pick 'n Pay Stores & 11,31 \\
\hline Putco & 11,22 \\
\hline Dunlop Africa & 10,61 \\
\hline Pepkor & 9,34 \\
\hline Lenco Holdings & 9,13 \\
\hline Grinrod Unicorn Group & 7,88 \\
\hline Glodina Holdings & 7,59 \\
\hline Sun International (Boputhatswana) & 6,55 \\
\hline Tongaat-Hulett & 5,87 \\
\hline Crookes Brothers & 2,58 \\
\hline
\end{tabular}

This ratio shows how efficient the two production factors in an organisation work together and that the one is backed by the other. One would expect that organisations with specialised, expensive non-current assets and highly skilled employees would have to increase their value added significantly in order to achieve an above average ratio in comparison to other less capital intensive organisations.

For the ratio, depreciation divided by salaries, it was found that none of the organisations could reach a ratio value of 65 percent. The highest value for a organisation was found for Autopage Holdings with a ratio value of 45,56 percent. Only four of the 33 organisations had ratio values of approximately 30 percent and higher. They are Autopage Holdings, SASOL, Toyota (South Africa) and Grindrod Unicorn Group. The rest had ratio values of less then 30 percent.

In comparison to capital intensive organisations in the United Kingdom that have ratios of 65 percent and more, it seems that South African capital intensive organisations do not do well. There could be two reasons for this occurrence. One could be that the employee cost of South African organisations exceeds that of organisations in the United Kingdom, which causes the ratio value to be smaller. A second reason might be that South African organisations do not reinvest in non-current assets at the same rate as do organisations in the United Kingdom.

\section{Capital investment}

The use of the ratios, operating income as a percentage of value added and non-current assets per employee, are employed to measure if organisations are able to reinvest in new non-current assets or train and develop their employees. Operating income, defined as the sum of depreciation and 
net profit before taxation, provides the means for reinvestment. The capital intensity ratio, non-current assets per employee, provides a measure for the relative capital intensity of an organisation.

One would typically expect that organisations that are more capital intensive, such as SASOL, Sun International (Boputhatswana) and Grindrod Unicorn, will have a higher operating margin to compensate for future investments. Organisations in the stores sector will expectantly have a smaller operating margin.

Table 4: Efficiency ratios

\begin{tabular}{|c|c|c|}
\hline & $\begin{array}{c}\text { Value added } \\
\div \\
\text { (salaries }+ \\
\text { depreciation) } \\
(\%) \\
\end{array}$ & $\begin{array}{c}\text { Depreciation } \\
\div \\
\text { salaries } \\
(\%)\end{array}$ \\
\hline & Median & Median \\
\hline AECI & $142,15 \%$ & $19,59 \%$ \\
\hline African Oxygen & $154,27 \%$ & $20,39 \%$ \\
\hline Allied Electronics & $143,84 \%$ & $8,65 \%$ \\
\hline Allied Technologies & $145,05 \%$ & $12,71 \%$ \\
\hline Autopage Holdings & $154,68 \%$ & $45,56 \%$ \\
\hline Barlow Rand & $136,38 \%$ & $14,36 \%$ \\
\hline Bicc Cafca & $202,91 \%$ & $26,11 \%$ \\
\hline Cashbuild & $134,13 \%$ & $12,70 \%$ \\
\hline Chemical Services & $165,74 \%$ & $11,03 \%$ \\
\hline Crookes Brothers & $162,81 \%$ & $21,07 \%$ \\
\hline Dunlop Africa & $147,59 \%$ & $10,42 \%$ \\
\hline Glodina Holdings & $119,97 \%$ & $11,17 \%$ \\
\hline Grinrod Unicorn Group & $134,46 \%$ & $30,41 \%$ \\
\hline Grintek & $127,56 \%$ & $5,90 \%$ \\
\hline Lenco Holdings & $134,11 \%$ & $12,52 \%$ \\
\hline Metro Cash \& Carry & $130,05 \%$ & $7,87 \%$ \\
\hline Midas & $132,42 \%$ & $7,22 \%$ \\
\hline Nampak & $149,20 \%$ & $17,15 \%$ \\
\hline Oceana Fishing Group & $187,82 \%$ & $22,06 \%$ \\
\hline Pepkor & $135,62 \%$ & $11,96 \%$ \\
\hline Pick 'n Pay Stores & $118,67 \%$ & $8,76 \%$ \\
\hline Power Technologies & $139,79 \%$ & $8,05 \%$ \\
\hline Pretoria Portland Cement Co & $187,53 \%$ & $27,66 \%$ \\
\hline Profurn & $169,47 \%$ & $4,11 \%$ \\
\hline Putco & $106,75 \%$ & $22,98 \%$ \\
\hline Reunert & $131,82 \%$ & $8,84 \%$ \\
\hline SASOL & $197,79 \%$ & $40,60 \%$ \\
\hline Siltek & $144,48 \%$ & $7,05 \%$ \\
\hline Sun International (Boputhatswana) & $174,92 \%$ & $20,02 \%$ \\
\hline Tiger Brands & $154,57 \%$ & $14,46 \%$ \\
\hline Tongaat-Hulett & $147,79 \%$ & $9,61 \%$ \\
\hline Toyota (South Africa) & $137,29 \%$ & $31,74 \%$ \\
\hline Trencor & $213,22 \%$ & $15,83 \%$ \\
\hline
\end{tabular}

From Figure 2 it would appear that capital intensive organisations such as Pretoria Portland Cement Organisation and Bicc Cafca have sufficient profits to reinvest in their non-current assets. These organisations have an operating margin above the trend line, which suggests that they are in a favourable position to reinvest. Grindrod Unicorn Group, African Oxygen and AECI appear to be in less favourable positions. These organisations fall below the trend line, indicating that they do not produce a high enough operating margin in order to reinvest. SASOL and Sun International
(Bophuthatswana) fall on the trend line. It would thus seem that these organisations follow the norm in terms of reinvestment in their non-current assets.

Table 5: Capital reinvestment ratios

\begin{tabular}{|c|c|c|}
\hline & $\begin{array}{c}\text { Operating } \\
\text { income } \div \text { Value } \\
\text { added } \\
(\%) \\
\end{array}$ & $\begin{array}{c}\text { Non-current } \\
\text { assets per } \\
\text { employee } \\
\left(R^{\prime} 000\right) \\
\end{array}$ \\
\hline & Median & $\begin{array}{c}\text { VA per } \\
\text { employee } \\
\div \\
\text { VA per non- } \\
\text { current assets }\end{array}$ \\
\hline AECI & $30,96 \%$ & 132,83 \\
\hline African Oxygen & $39,06 \%$ & 138,60 \\
\hline Allied Electronics & $37,97 \%$ & 28,84 \\
\hline Allied Technologies & $45,95 \%$ & 33,30 \\
\hline Autopage Holdings & $45,51 \%$ & 51,71 \\
\hline Barlow Rand & $35,13 \%$ & 92,41 \\
\hline Bicc Cafca & $61,12 \%$ & 167,89 \\
\hline Cashbuild & $33,68 \%$ & 30,21 \\
\hline Chemical Services & $40,60 \%$ & 64,16 \\
\hline Crookes Brothers & $49,01 \%$ & 45,23 \\
\hline Dunlop Africa & $36,99 \%$ & 48,90 \\
\hline Glodina Holdings & $16,05 \%$ & 62,52 \\
\hline Grinrod Unicorn Group & $35,47 \%$ & 227,71 \\
\hline Grintek & $31,58 \%$ & 21,01 \\
\hline Lenco Holdings & $29,26 \%$ & 11,32 \\
\hline Metro Cash \& Carry & $29,03 \%$ & 17,55 \\
\hline Midas & $24,74 \%$ & 9,12 \\
\hline Nampak & $42,31 \%$ & 87,60 \\
\hline Oceana Fishing Group & $56,82 \%$ & 77,03 \\
\hline Pepkor & $29,79 \%$ & 22,04 \\
\hline Pick 'n Pay Stores & $24,71 \%$ & 21,38 \\
\hline Power Technologies & $32,95 \%$ & 31,05 \\
\hline Pretoria Portland Cement Co & $57,52 \%$ & 263,52 \\
\hline Profurn & $38,78 \%$ & 6,99 \\
\hline Putco & $23,54 \%$ & 36,29 \\
\hline Reunert & $32,73 \%$ & 30,01 \\
\hline SASOL & $61,56 \%$ & 400,89 \\
\hline Siltek & $39,23 \%$ & 22,91 \\
\hline Sun International (Boputhatswana) & $49,42 \%$ & 222,64 \\
\hline Tiger Brands & $41,19 \%$ & 54,49 \\
\hline Tongaat-Hulett & $32,81 \%$ & 84,86 \\
\hline Toyota (South Africa) & $39,18 \%$ & 120,91 \\
\hline Trencor & $47,78 \%$ & 43,26 \\
\hline
\end{tabular}

From Table 5 the following organisations were identified as most capital intensive: SASOL, Pretoria Portland Cement Organisation, Grindrod Unicorn Group, Sun International (Boputhatswana), Bicc Cafca, African Oxygen and AECI.

The labour intensive organisations such as Pick ' $n$ Pay, Midas and Glodina Holdings all fall below the trend line. Although these organisations are not that capital intensive and thus not dependent on their non-current assets for manufacturing and production purposes, they should still strive to reach the trend line. Reinvestment in their labour force could prove to be to their advantage in creating value. Profurn, a organisation known for its labour intensiveness, is above the trend line. This shows that additional funds are available for reinvestment in its workforce. 


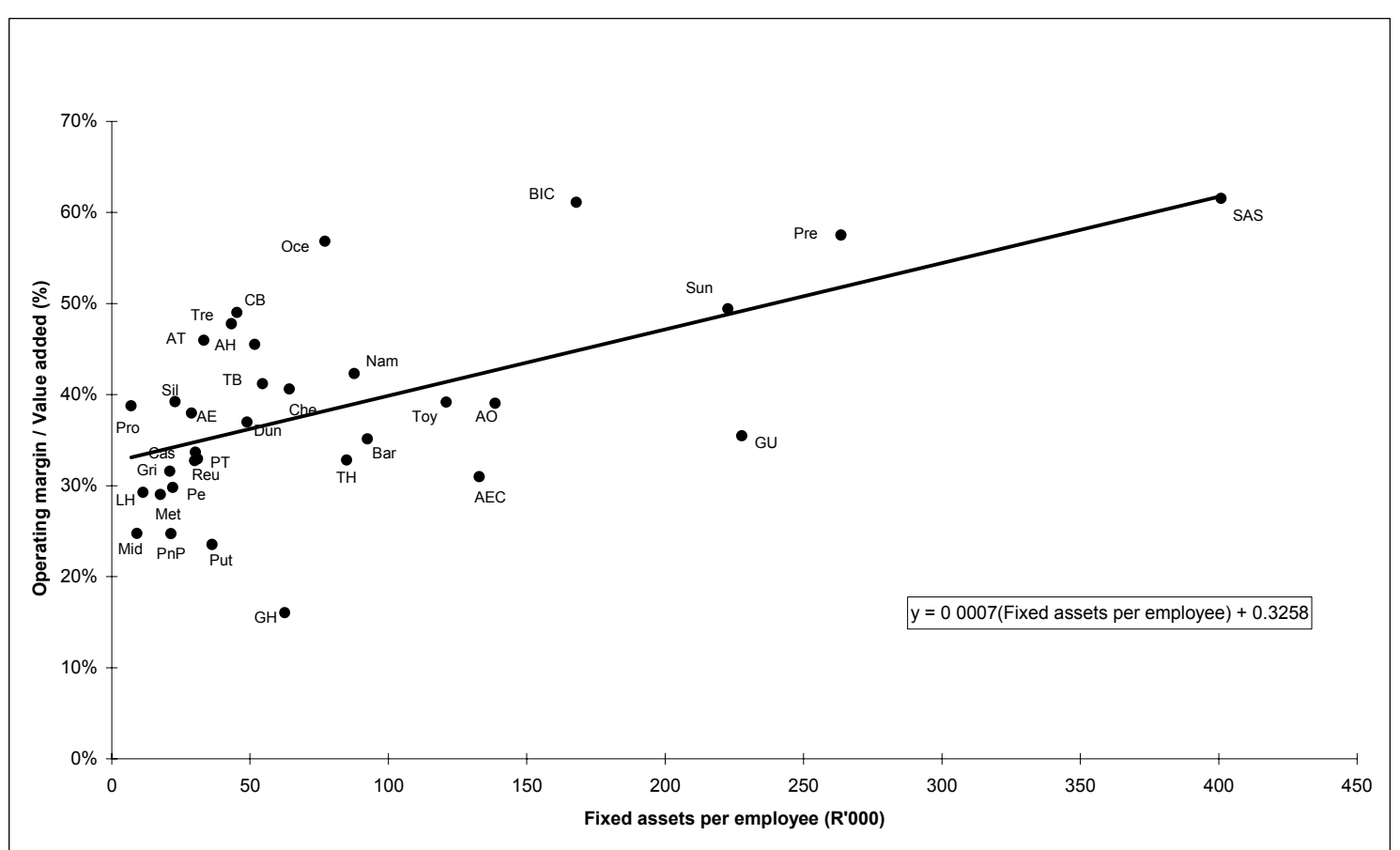

Figure 2: Operating margin as a function of capital intensity per organisation: median

Organisations that move along the trend line on either side are Toyota (South Africa) and Nampak. This is an indication of reinvestment according to the standard that was set by all the organisations in the sample. This could however not be enough for those organisations within their specific sectors, but rather sets the norm for the companies in this sample, regardless of their industry.

\section{Profit strategy and vertical integration}

\section{Market influence}

Table 6 is a listing of the organisations in the sample, sorted in descending order according to the median for this ratio, profit before taxation as a percentage of sales.

At the top of the list are SASOL, Sun International (Boputhatswana), Crookes Brothers and Trencor. These organisations have a median for this ratio of 20 percent and more. These organisations exercise the most market influence of all the organisations in the sample.

At the bottom of the list are Metro Cash \& Carry, Pick ' $n$ Pay Stores, Cashbuild and Glodina Holdings. These organisations have the least market influence of all organisations in this sample set.

\section{Supply influence}

Table 7 provides a listing of organisations for the ratio profit before taxation as a percentage of value added. These organisations are sorted in descending order according to the median for the ratio, profit before taxation as a percentage of value added.
Table 6: Profit before taxation $\div$ Sales

\begin{tabular}{|c|c|}
\hline & $\begin{array}{c}\text { Profit before taxation } \\
\div \text { Sales } \\
(\%)\end{array}$ \\
\hline Organisations & Median \\
\hline SASOL & $22,93 \%$ \\
\hline Sun International (Boputhatswana) & $22,85 \%$ \\
\hline Crookes Brothers & $21,59 \%$ \\
\hline Trencor & $20,40 \%$ \\
\hline Pretoria Portland Cement Co & $19,19 \%$ \\
\hline African Oxygen & $14,63 \%$ \\
\hline Allied Technologies & $14,58 \%$ \\
\hline Dunlop Africa & $13,11 \%$ \\
\hline Profurn & $12,49 \%$ \\
\hline Bicc Cafca & $11,16 \%$ \\
\hline Nampak & $11,13 \%$ \\
\hline Oceana Fishing Group & $10,90 \%$ \\
\hline Allied Electronics & $9,69 \%$ \\
\hline Power Technologies & $8,76 \%$ \\
\hline Chemical Services & $8,69 \%$ \\
\hline Tongaat-Hulett & $8,39 \%$ \\
\hline Reunert & $8,16 \%$ \\
\hline Lenco Holdings & $7,88 \%$ \\
\hline Tiger Brands & $6,87 \%$ \\
\hline Grinrod Unicorn Group & $6,83 \%$ \\
\hline AECI & $6,44 \%$ \\
\hline Barlow Rand & $6,29 \%$ \\
\hline Siltek & $6,13 \%$ \\
\hline Grintek & $5,97 \%$ \\
\hline Autopage Holdings & $4,14 \%$ \\
\hline Toyota (South Africa) & $3,84 \%$ \\
\hline Putco & $3,58 \%$ \\
\hline Midas & $3,44 \%$ \\
\hline Pepkor & $3,34 \%$ \\
\hline Glodina Holdings & $2,91 \%$ \\
\hline Cashbuild & $2,74 \%$ \\
\hline Pick 'n Pay Stores & $2,41 \%$ \\
\hline Metro Cash \& Carry & $1,69 \%$ \\
\hline
\end{tabular}


Table 7: Profit before taxation $\div$ Value added

\begin{tabular}{lc}
\hline & $\begin{array}{c}\text { Profit before taxation } \\
\div \\
\text { Value added } \\
\mathbf{( \% )}\end{array}$ \\
& Median \\
\hline \multicolumn{1}{c}{ Organisations } & $49,19 \%$ \\
\hline Bicc Cafca & $47,90 \%$ \\
Pretoria Portland Cement Co & $46,44 \%$ \\
SASOL & $44,58 \%$ \\
Oceana Fishing Group & $41,81 \%$ \\
Trencor & $40,96 \%$ \\
Sun International (Boputhatswana) & $38,64 \%$ \\
Allied Technologies & $38,13 \%$ \\
Autopage Holdings & $37,18 \%$ \\
Crookes Brothers & $36,72 \%$ \\
Siltek & $36,39 \%$ \\
Profurn & $34,54 \%$ \\
Chemical Services & $32,88 \%$ \\
Tiger Brands & $31,54 \%$ \\
Nampak & $30,91 \%$ \\
Dunlop Africa & $30,36 \%$ \\
Allied Electronics & $28,26 \%$ \\
African Oxygen & $27,63 \%$ \\
Power Technologies & $27,29 \%$ \\
Grintek & $27,06 \%$ \\
Reunert & $26,88 \%$ \\
Tongaat-Hulett & $26,55 \%$ \\
Barlow Rand & $25,45 \%$ \\
Cashbuild & $23,22 \%$ \\
Metro Cash \& Carry & $22,52 \%$ \\
Pepkor & $21,91 \%$ \\
Toyota (South Africa) & $20,99 \%$ \\
Lenco Holdings & $20,14 \%$ \\
AECI & $19,47 \%$ \\
Midas & $19,30 \%$ \\
\hline & $17,81 \%$ \\
Prinrod Unicorn Group & $6,73 \%$ \\
\hline
\end{tabular}

The values range from less than ten percent to approximately 49 percent. Organisations that indicate a ratio of more than 40 percent are Bicc Cafca, Pretoria Portland Cement Organisation, SASOL, Oceana Fishing Group, Trencor and Sun International (Bophuthatswana). These organisations are mostly in the manufacturing industries, except for Sun International (Boputhatswana). This organisation is more likely to be classified in a service industry, but the type of service that is offered by this organisation is much sought after. The market is more than willing to pay for the pleasure that it gets from gambling and the use of these hotels. The manufacturing organisations are in a favourable position to sell the products that they have made through their own resources to the market. These organisations can ask a sizable profit and the market is still willing to pay for it.

Right at the bottom of the list are Putco and Glodina Holdings once again. These organisations are not able to exert either market or supply influence. Other organisations residing at the bottom of the list are Pick ' $n$ Pay Stores, Grindrod Unicorn Group and Midas. These organisations were not able to reach a mean ratio value of 20 percent. These organisations do not wield a high level of supply influence. They are not able to ask a high premium for their services or goods.

\section{Vertical integration measurement}

Value added is an amount which indicates to what degree a organisation was able to sell products and services that were brought about due to its own processes and activities. Table 1 provides data for vertical integration measurement.

Crookes Brothers has shown that it exerts a high level of market influence and here it sits in the top position yet again. The organisation with the second highest values for this ratio is Putco. This organisation did not rank high on either of the previous two ratios discussed. This implies that it does not have a very high profit before taxation median over the eleven year period. In the third place is Sun International (Boputhatswana). This organisation has shown to be a top performer in both of the previous ratio calculations. These three organisations, as well as African Oxygen, were able to score values in excess of 50 percent for the median of this ratio. This means that these four organisations are definitely vertically integrated and own their suppliers and/or market outlets to a great extent.

On the opposite side of the scale resides Metro Cash and Carry. This organisation, as well as Cashbuild, Pick ' $n$ Pay Stores and Pepkor, have ratio values of less than 15 percent. This suggests that no or little vertical integration exists. These organisations do not own the suppliers of the goods that they sell to the market.

\section{$\mathrm{K}$ index}

A way to combine both ratios for market and supply influence into one index was developed by Bryant (1989:4142). This ratio provides a good indication of the overall business control level that is put forth by a organisation and could prove to be a useful tool to measure organisation performance.

Table 8 provides a listing of the $\mathrm{K}$ factor per organisation and is sorted in descending order. The $\mathrm{K}$ factor is a reference tool that indicates if a organisation is operating at or near its optimal position. Bryant (1989:42) stated that an organisation with a $\mathrm{K}$ factor in the region of 1,7 does reasonably well. If the capital intensity is very low, a $\mathrm{K}$ factor of around 1,4 is also acceptable.

At the top of the list features SASOL as the top performer of all the organisations in the sample, by now a familiar sighting in the top ranks of the ratios in this section. Other organisations with a $\mathrm{K}$ factor higher than two are Pretoria Portland Cement Organisation, Bicc Cafca, Sun International (Boputhatswana), Trencor, Crookes Brothers and Oceana Fishing Group. These organisations appear to have a far better level of overall business control than all the other organisations in the sample. 
The worst performers in this section are Putco, Glodina Holdings, Pick ' $n$ Pay Stores and Midas who all have a factor of less than 1,3. These organisations show the least overall business control of all the organisations in the sample. Other organisations that had a $\mathrm{K}$ factor of less than 1,4 were Metro Cash and Carry, Toyota (South Africa), Grindrod Unicorn Group, AECI, Pepkor, Lenco Holdings and Cashbuild. Organisations in the stores sector are less capital intensive and this ratio value is not too bad for them. However, a organisation such as Toyota (South Africa) which is definitely a capital intensive organisation should be able to perform far better.

\section{Table 8: $\mathrm{K}$ index}

\begin{tabular}{lc}
\hline & K Index \\
\hline \multicolumn{1}{c}{ Organisation } & Median \\
\hline SASOL & 2,45 \\
Pretoria Portland Cement Co & 2,37 \\
Bicc Cafca & 2,22 \\
Sun International (Boputhatswana) & 2,20 \\
Trencor & 2,17 \\
Crookes Brothers & 2,07 \\
Oceana Fishing Group & 2,06 \\
Allied Technologies & 1,82 \\
Profurn & 1,80 \\
Autopage Holdings & 1,69 \\
Siltek & 1,69 \\
Chemical Services & 1,67 \\
Dunlop Africa & 1,67 \\
Nampak & 1,64 \\
African Oxygen & 1,64 \\
Allied Electronics & 1,62 \\
Tiger Brands & 1,61 \\
Power Technologies & 1,53 \\
Reunert & 1,50 \\
Tongaat-Hulett & 1,49 \\
Grintek & 1,46 \\
Barlow Rand & 1,46 \\
Cashbuild & 1,38 \\
Lenco Holdings & 1,37 \\
Pepkor & 1,34 \\
GECI & 1,34 \\
Toyota (South Africa) & 1,34 \\
Metro Cash \& Carry & 1,33 \\
Midas & 1,32 \\
Pick 'n Pay Stores & 1,28 \\
Putco & 1,25 \\
\hline & \\
\hline &
\end{tabular}

Figure 3 indicates how organisations with similar overall business control levels are grouped together in zones, but at the same time also shows how they differ in terms of their degree of vertical integration. A comparison of the top two performers in terms of the $\mathrm{K}$ index reveals that SASOL has a higher degree of vertical integration than that of Pretoria
Portland Cement Organisation. SASOL and Sun International (Bophuthatswana) display higher levels of market influence than Pretoria Portland Cement Organisation and Bicc Cafca, but it is the latter that outperform them in terms of their degree of supply influence.

It should be noted that two methods can be used to calculate value added as a percentage of sales. This is displayed in Table 9. Differences were found between the two methods and the organisations with the highest variances are Autopage Holdings $(15,72 \%)$ and Crookes Brothers $(11,73 \%)$. These differences are attributed to the fact that the sample does not represent a normal distribution. This has a significant impact on the placement of the organisations on the graph in Figure 3. Values as calculated in method two should be used to interpret the graph. This is so due to the fact that the formula used on the $\mathrm{x}$ - and $\mathrm{y}$-axis were used to derive the value for value added as a percentage of sales. Method one was used for Table 1.

\section{Summary}

This article sought to investigate the significance of value added ratio analysis and to examine whether it could be used as a tool to assess organisation strength. Various ratios that were obtained from the components of a value added statement were examined. The ratios were divided into different sections of which the purpose was to examine various areas of operation of organisations.

Value added as a percentage of sales indicated that some organisations were able to contribute more in terms of their income to the gross domestic product than others. These organisations were able to convert high proportions, in some cases up to 50 percent and more, of their sales into value added. It appeared that organisations in manufacturing industries were more able to wield a high value for this ratio. Organisations within same sectors also indicated that, although they were classified as similar industry organisations, they could differ considerably from each other. In such cases it demonstrated a high level of leadership efficiency that made some organisations excel within their sectors as compared to others.

Productivity measurement indicated the degree to which organisations were able to employ their productivity factors to produce value added. The ratio, non-current assets per employee, gave an indication of the proportion to which organisations employ non-current assets and employees. Organisations that were classified as being capital intensive had a high value for this ratio. Other ratios used in this section to measure the scale of productivity of their production factors provided insight on how organisations could increase their value added. It was interesting to see that some organisations were able to wield a high value for the value added to sales ratio, but their production factor productivity was not very high in comparison to other organisations in the sample. This was an indication that such organisations could improve their value added to sales proportion if they were able to find an optimal point of usage between their non-current assets and their employees. 


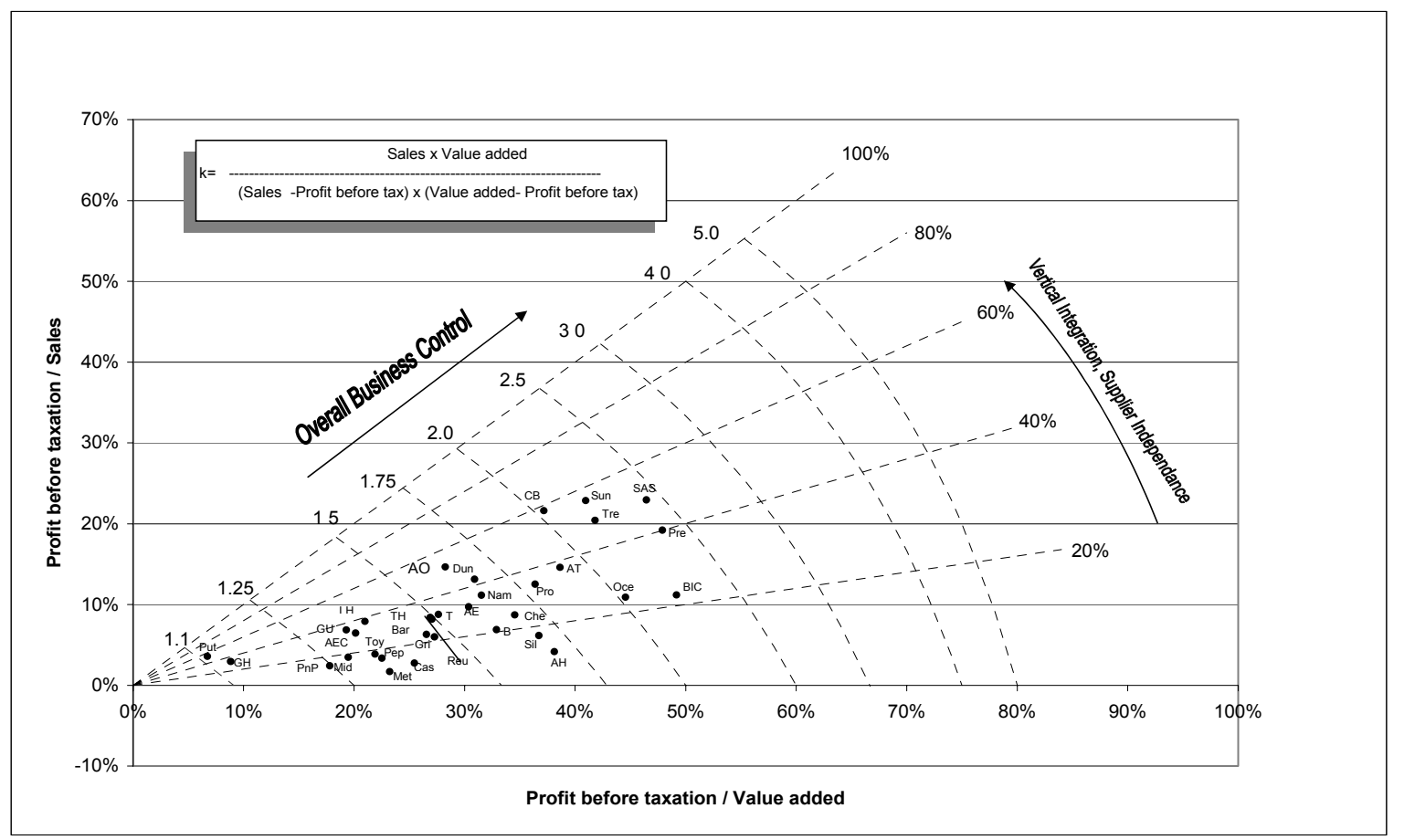

Figure 3: Overall business control per organisation: median

Table 9: Two methods to calculate value added as a percentage of sales

\begin{tabular}{|c|c|c|c|}
\hline & $\begin{array}{c}\text { Value added as a percentage of } \\
\text { sales } \\
\text { Method one } \\
\end{array}$ & $\begin{array}{l}\text { Value added as a percentage of sales } \\
\text { Method two }\end{array}$ & \\
\hline & Median & Median & \\
\hline & $\begin{array}{l}\text { Value added } \\
\div \text { Sales } \\
\end{array}$ & $\begin{array}{c}\text { (Profit before tax/Sales) } \\
\div \text { (Profit before tax/Value added) }\end{array}$ & $\begin{array}{c}\text { Variance in calculation from } \\
\text { method one }\end{array}$ \\
\hline AECI & $31,26 \%$ & $31,96 \%$ & $-0,70 \%$ \\
\hline African Oxygen & $51,05 \%$ & $51,79 \%$ & $-0,73 \%$ \\
\hline Allied Electronics & $31,17 \%$ & $31,91 \%$ & $-0,74 \%$ \\
\hline Allied Technologies & $31,88 \%$ & $37,74 \%$ & $-5,85 \%$ \\
\hline Autopage Holdings & $26,57 \%$ & $10,85 \%$ & $15,72 \%$ \\
\hline Barlow Rand & $25,87 \%$ & $23,71 \%$ & $2,16 \%$ \\
\hline Bicc Cafca & $22,69 \%$ & $22,69 \%$ & $0,00 \%$ \\
\hline Cashbuild & $11,91 \%$ & $10,75 \%$ & $1,16 \%$ \\
\hline Chemical Services & $25,98 \%$ & $25,14 \%$ & $0,83 \%$ \\
\hline Crookes Brothers & $69,80 \%$ & $58,08 \%$ & $11,73 \%$ \\
\hline Dunlop Africa & $41,67 \%$ & $42,40 \%$ & $-0,73 \%$ \\
\hline Glodina Holdings & $33,12 \%$ & $32,96 \%$ & $0,17 \%$ \\
\hline Grinrod Unicorn Group & $34,62 \%$ & $35,40 \%$ & $-0,77 \%$ \\
\hline Grintek & $24,24 \%$ & $21,89 \%$ & $2,35 \%$ \\
\hline Lenco Holdings & $37,01 \%$ & $37,55 \%$ & $-0,55 \%$ \\
\hline Metro Cash \& Carry & $7,79 \%$ & $7,28 \%$ & $0,51 \%$ \\
\hline Midas & $15,85 \%$ & $17,68 \%$ & $-1,83 \%$ \\
\hline Nampak & $35,35 \%$ & $35,30 \%$ & $0,05 \%$ \\
\hline Oceana Fishing Group & $23,99 \%$ & $24,45 \%$ & $-0,45 \%$ \\
\hline Pepkor & $14,85 \%$ & $14,82 \%$ & $0,03 \%$ \\
\hline Pick 'n Pay Stores & $12,90 \%$ & $13,54 \%$ & $-0,64 \%$ \\
\hline Power Technologies & $30,21 \%$ & $31,70 \%$ & $-1,49 \%$ \\
\hline Pretoria Portland Cement Co & $44,23 \%$ & $40,06 \%$ & $4,17 \%$ \\
\hline Profurn & $36,27 \%$ & $34,31 \%$ & $1,96 \%$ \\
\hline Putco & $58,49 \%$ & $53,18 \%$ & $5,31 \%$ \\
\hline Reunert & $29,73 \%$ & $30,15 \%$ & $-0,42 \%$ \\
\hline SASOL & $47,76 \%$ & $49,37 \%$ & $-1,61 \%$ \\
\hline Siltek & $17,11 \%$ & $16,71 \%$ & $0,40 \%$ \\
\hline Sun International (Boputhatswana) & $53,29 \%$ & $55,78 \%$ & $-2,49 \%$ \\
\hline Tiger Brands & $21,75 \%$ & $20,89 \%$ & $0,86 \%$ \\
\hline Tongaat-Hulett & $30,44 \%$ & $31,22 \%$ & $-0,78 \%$ \\
\hline Toyota (South Africa) & $18,37 \%$ & $17,52 \%$ & $0,85 \%$ \\
\hline Trencor & $48,83 \%$ & $48,79 \%$ & $0,04 \%$ \\
\hline
\end{tabular}


An inherent danger lurks in the productivity measurement of organisations as described previously. Organisations could decide to decrease their production factors and show high levels of productivity relative to others. This is for obvious reasons not the preferred method to increase productivity and it is for this reason that efficiency and capital investment measurement were also tested. The purpose of the efficiency ratios was to measure organisations against each other by means of their use of production factors. Organisations that were previously described as capital intensive were expected to have higher proportions of depreciation to employee costs than organisations that were more labour intensive. It was however found that capital intensive organisations did not reinvest at the same rate as their counterparts in the United Kingdom. This could drastically affect their efficiency of production, as these organisations are reliant on their non-current assets to produce merchandise for sale.

Capital investment gave an indication of the means to reinvest in the future. This is not only applicable to noncurrent assets, but also employees. The operating margin of a organisation provides the means to reinvest and it was this element that was tested against the capital intensiveness ratio of organisations to see whether or not they could improve on their reinvestment in production factors. It was found that if organisations wished to retain their current levels of sustainability and have any intention of growth in the future, they would have to increase their spending on production factors. The means to spend on production factors did exist in most cases.

The last section on profit strategy and vertical integration was an attempt to bring all the ratios together and show how organisations compared with each other. Now, armed with the knowledge of their inherent structures and spending levels on their production factors, it was interesting to see how organisations were able to generate the value added levels that they did earlier and even identify those that could improve.

Organisations were compared in terms of the profit that they generate due to their own production abilities and also in terms of their ability to negotiate beneficial contracts with their suppliers. Organisations that were able to achieve high values in both these ratios had a high level of overall business control. In comparison to the ratio, value added as a percentage of sales, it was found that a close link existed between this ratio and overall business control. Organisations that did well in this ratio also exerted a high degree of overall business control.

Value added ratio analysis is the only technique that distinguishes between costs incurred by the organisation through its own production processes and those that were incurred due to others outside of the organisation. It could contribute largely to the make or buy decision, which in return affects the corporate strategy of an organisation. Through the employment of the models and techniques described in this article, management of organisations could create more efficient structures to reach their optimal position of operation.

\section{References}

Accounting Standards Steering Committee. 1975. The corporate report. London: Moorgate Place.

Bannister, J.W. \& Riahi-Belkaoui, A. 1991. 'Value added and corporate control in the U.S', Journal of International and Financial Management and Accounting, 3:3: 241-257.

Bryant, J. 1989. 'Assessing Organisation strength using added value', Long range planning, 22(3), 34-44.

Haller, A. \& Stolowy, H. 'Value added in financial accounting. A comparative study between Germany and France'. [online]

URL:http://campus.hec fr/profs/stolowy/perso/articles/Va.pd f. Accessed 15 July 2003.

Hamman, W.D. \& Burger, J. 1999. 'RSA value-added statements: Certain ratios 1991-1997'. In Terblanch, N. (Ed.). Proceedings of the $11^{\text {th }}$ Annual Conference of the Southern Africa Institute for Management Scientists, Stellenbosch: SAIMS.

Jordaan, A.C., Smit, E. v.d.M \& Hamman, W.D. 1994. 'An investigation into the normality of the distributions of financial ratios of listed South African industrial organisations', South African Journal for Business Management, 25(2): 65-71.

Morley, M.F. 1979. 'The value added statement in Britain', Accounting Review, 54(3):618-629.

Riahi-Belkaoui, A. 1992. Value added reporting: Lessons for the United States. New York: Quorum Books.

Rutherford, B.A. 1981. 'Five fallacies about value added', Management Accounting, 31-33.

Steyn, W. \& Hamman, W.D. 2002. 'A conceptual model for the interpretation and evaluation of VAS', Accountancy $S A$, July:16-19.

United Kingdom. 2003. The value added scoreboard 2003. London: Department of Trade and Industry, Business Finance \& Investment Unit. 
APPENDIX A

LEGEND OF ORGANISATIONS

\begin{tabular}{rc}
\hline Legend & Organisations \\
\hline AE & Allied Electronics \\
AEC & AECI \\
AH & Autopage Holdings \\
AO & African Oxygen \\
AT & Allied Technologies \\
Bar & Barlow Rand \\
BIC & Bicc Cafca \\
Cas & Cashbuild \\
CB & Crookes Brothers \\
Che & Chemical Services \\
Dun & Dunlop Africa \\
GH & Glodina Holdings \\
Gri & Grintek \\
GU & Grinrod Unicorn Group \\
LH & Lenco Holdings \\
Met & Metro Cash \& Carry \\
Mid & Midas \\
Nam & Nampak \\
Oce & Oceana Fishing Group \\
Pep & Pepkor \\
PnP & Pick 'n Pay Stores \\
Pre & Pretoria Portland Cement Organisation \\
Pro & Profurn \\
PT & Power Technologies \\
Put & Putco \\
Reu & Reunert \\
SAS & SASOL \\
Sil & Siltek \\
Sun & Sun International (Boputhatswana) \\
TB & Tiger Brands \\
TH & Tongaat-Hulett \\
Toy & Toyota (South Africa) \\
Tre & Trencor \\
& \\
\hline & \\
\hline
\end{tabular}

